\title{
Chemical composition and insecticidal activity of Cymbopogon citratus essential oil from Cuba and Brazil against housefly
}

\author{
Composição química e atividade inseticida do óleo essencial de Cymbopogon citratus de
} Brasil e Cuba contra mosca doméstica

Zeneida Teixeira Pinto ${ }^{1,2 *}$; Félix Fernández Sánchez ${ }^{3}$; Arith Ramos dos Santos ${ }^{4}$; Ana Claudia Fernandes Amaral ${ }^{4}$; José Luiz Pinto Ferreira ${ }^{4}$; Julio César Escalona-Arranz; Margareth Maria de Carvalho Queiroz ${ }^{6}$

\author{
${ }^{1}$ Laboratório de Educação em Ambiente e Saúde, Instituto Oswaldo Cruz, Fundação Oswaldo Cruz - Fiocruz, \\ Rio de Janeiro, RJ, Brasil \\ ${ }^{2}$ Programa de Pós-graduação em Ciências Veterinárias, Instituto de Veterinária, Universidade Federal Rural do \\ Rio de Janeiro - UFRRJ, Itaguaí, RJ, Brasil \\ ${ }^{3}$ Laboratorio de Aseguramiento de la Calidad, Moa, Holguín, Cuba \\ ${ }^{4}$ Laboratório de Plantas Medicinais e Derivados, Farmanguinhos, Fundação Oswaldo Cruz - Fiocruz, Rio de Janeiro, RJ, Brasil \\ ${ }^{5}$ Departamento de Farmacia, Universidad de Oriente, Santiago de Cuba, Cuba \\ ${ }^{6}$ Laboratório de Transmissores de Leishmanioses, Setor de Entomologia Médica e Forense, Instituto Oswaldo Cruz, \\ Fundação Oswaldo Cruz - Fiocruz, Rio de Janeiro, RJ, Brasil
}

Received August 26, 2014

Accepted November 17, 2014

\begin{abstract}
Essential oil of Cymbopogon citratus collected from Brazil and Cuba was tested to a chemical characterization and then was tested on the post-embryonic development of Musca domestica. The chemical composition analysis by GCMS of the oils from Brazil/Cuba allowed the identification of 13 and 12 major constituents respectively; nine of them common to both. In the both oils, the main components were the isomers geranial and neral, which together form the compound citral. This corresponds to a total of $97.92 \% /$ Brazil and $97.69 \% / C u b a$ of the compounds identified. The monoterpene myrcene, observed only in the sample of Cuba, presented a large relative abundance (6.52\%). The essential oil of C. citratus (Brazil/Cuba) was dissolved in DMSO and tested at concentrations of 5, 10, 25, 50, 75 and 100\% and citral was prepared by mixing $16.8 \mathrm{mg}$ with $960 \mu \mathrm{L}$ DMSO. Both essential oils and monoterpene citral were applied topically to newly-hatched larvae ( $1 \mu \mathrm{L} /$ larva). The results showed a lethal concentration (LC50) of 4.25 and $3.24 \%$ for the Brazilian and Cuban essential oils, respectively. Mortalities of larval and newly-hatched larvae to adult periods were dose-dependent for the two both oils as for monoterpene citral, reaching $90 \%$. Both essential oils and citral caused morphological changes in adult specimens.
\end{abstract}

Keywords: Vector control, essential oil, house-fly, lemongrass, Cymbopogon citratus.

\section{Resumo}

O óleo essencial de Cymbopogon citratus, coletado no Brasil e em Cuba, foi caracterizado quimicamente e testado no desenvolvimento pós-embrionário de Musca domestica. A análise da composição química dos óleos essenciais (Brasil/Cuba), por Cromatografia Gasosa acoplada ao espectrômetro de massa (GC-EM), permitiu a identificação de 13 e 12 componentes principais, respectivamente; nove deles comuns aos dois. Em ambos os óleos, os principais componentes foram os isômeros geranial e neral, que, juntos, formam o composto citral. Esse corresponde a um total de 97,92\%/Brasil e 97,69\%/Cuba dos compostos identificados. O monoterpeno mirceno, observado na amostra cubana, apresentou grande abundância relativa (6,52\%). O óleo de C. citratus (Brasil/Cuba) foi dissolvido em DMSO, obtendo-se as concentraçóes de 5, 10, 25,75 e $100 \%$; e o citral $(16,8 \mathrm{mg})$ foi misturando com $960 \mathrm{~mL}$ de DMSO. Tanto o óleo essencial como o monoterpeno citral foram aplicados topicamente nas neolarvas ( $1 \mu \mathrm{L} / \mathrm{larva})$. Os resultados mostraram uma concentração letal (CL50)

\footnotetext{
*Corresponding author: Zeneida Teixeira Pinto, Av. Brasil, 4365, Pavilhão Lauro Travassos, Sala 22, Térreo, CEP 21040-900, Rio de Janeiro, RJ, Brazil, e-mail: zeneida@ioc.fiocruz.br
} 
de 4,25\% e 3,24\% para o óleo essencial brasileiro e cubano, respectivamente. As mortalidades do período larval e o de neo-larva a adulto foram dose-dependentes, tanto para os óleos como para o monoterpeno citral, podendo chegar a 90\%. Ambos os óleos essenciais e citral causaram alteraçóes morfológicas nos espécimes adultos.

Palavras-chave: Controle de vetores, óleo essencial, mosca doméstica, lemongrass, Cymbopogon citratus.

\section{Introduction}

The use of chemical insecticides in pest control induces insect resistance, and impact the environment through water and soil contamination, becoming toxic to vertebrates (PRADO, 2003). Thereby, multiple worldwide efforts to use botanical products to control insect vectors and pests appeared in the latest years. Biopesticides offer an alternative to insect control in which the damage to the environment is minimized, reaching only target organisms, with a minimal residual activity against predators, parasites and pollinator insects (LIU et al., 2000), making its use appropriate in integrated pest management programs (ISMAN, 2006; KOUL et al., 2008).

Plants and their natural enemies (insects, bacteria or viruses) have undergone a co-evolution process in which a new plant resistance character that reduces enemy attack is developed. The essential oils are a type of metabolite with this function, characterized by complex mixtures of monoterpenoids and sesquiterpenoids as major metabolites. The number and quantities of compounds in the essential oil produced by a single plant can change with the environment characteristic, place of collection, plant age and other conditions, but in general, the major compounds remain as a significative chemical marker. Due to the volatile, odorous and lipophylic characteristics of the essential oils, they can be toxic to insects, induce behavioral modifications, provoke direct disruption of specific physiological routes related to neuroendocrine system and in their reproduction (PRATES \& SANTOS, 2002; GARCIA \& AZAMBUJA, 2004). In addition, essential oils have been shown to be relatively non-toxic to fish, birds and mammals and easily biodegrade in the environment (KUMAR et al., 2012), turning them into good biopesticides.

Diptera Muscoid presents a great medical-sanitary importance and is closely related to animals and human environment, acting as an important vector of pathogens, such as bacteria, protozoa cysts and oocysts, helminthes, fungi and viruses (VAZIRIANZADEH et. al., 2008; BARIN et al., 2010), besides being responsible for the production of myiasis in humans and animals (ZUMPT, 1985). The immature stages of some species of these flies develop in animal and plant decaying organic matter such as feces, garbage, corpses and carrion (GRABOVAC \& PETRIĆ, 2003).

Some studies revealed satisfactory results from the use of several essential oils for insect management such as the cosmopolitan pest house fly, Musca domestica L. (PAVELA, 2008); malarian vector mosquito, Anopheles gambiae Giles (McALLISTER \& ADAMS, 2010); parasitic mites of the honeybees bee Varroa destructor (ANDERSON \& TRUEMAN, 2000); Acari: Varroidae (GHASEMI et al., 2011); and the maize weevil adults, Sitophilus zeamais Motschulky (FAZOLIN et al., 2007).

The essential oil of Cymbopogon citratus (DC) Stapf (Poaceae), most known as "lemongrass", is commonly used by folk medicine in many countries. Native from India and Southeast Asia, it is distributed in numerous tropical countries, including Brazil (DUARTE \& ZANETI, 2004; SOUSA et al., 2010). There are several popular uses for this plant, including treatment for stomach pains, diarrhea (TANGPU \& YADAV, 2006), also having several pharmacological activities such as anti-amoebic and as antifungal (SHAH et al., 2011). Also it has been reported as potentially useful against insects (CAVALCANTI et al., 2004; KUMAR et al., 2013). Recently, some studies revealed that C. citratus essential oil and their main components (citral and 1.8 cineole), are important repellent and insecticide against housefly, but these studies are focused mainly in the instant effectiveness after application and not in long time effect. (KUMAR et al., 2011b, 2013; SINTHUSIRI \& SOONWERA, 2013). As of today, no study considered the effect of the essential oil in all the stages of the fly's life cycle; that's why it became important to reveal the effect of those essential oils in the post-embryonic development of $M$. domestica.

This report describes the evaluation of the chemical composition and insecticidal activity of $C$. citratus essential oil collected in Brazil and Cuba and its major compound (Citral) on the post-embryonic development of $M$. domestica.

\section{Materials and Methods}

\section{Plant collection and identification}

The Brazilian lemongrass fresh leaves were collected at Laboratory of Cultivation and Biomass Production of Farmaguinhos/Fiocruz- Jacarepaguá campus, Rio de Janeiro, Brazil (22087'49”S, 4324'53”W). A voucher specimen was deposited at Rio de Janeiro Botanical Garden Herbarium (RB) under the number RB3273021. The Cuban specimen was collect in the district of Miraflores, municipality of Moa, Holguín, Cuba $\left(20^{\circ} 38^{\prime} 21^{\prime \prime} \mathrm{N}-75^{\circ} 01^{\prime} 44^{\prime \prime} \mathrm{W}\right)$. The identification of the species and the quality parameters of vegetable drugs were secured by the Company of Agriculture municipality of Moa, the exclusive plant provider in this region of Cuba. A voucher specimen was deposited at BSC Herbarium under the number 16443.

\section{Extraction and component characterization by Gas Chromatographic mass spectrometry (GC-MS) analysis}

Fresh leaves of $C$. citratus were extracted by hydrodistillation using a "Clevenger type apparatus", as recommended by the Anvisa (2010). The chemical composition analysis of $C$. citratus oils (Brazil and Cuba) was done by High Resolution Gas Chromatography (HRGC) coupled to a mass spectrometer (MS). The gas chromatograph equipment model HP7590 (Agilent 
Technologies, USA), equipped with DB-5MS capillary column produced by the same company with dimensions $30 \mathrm{~m} \times 0.32 \mathrm{~m}$ and $0.25 \mathrm{~mm}$ thick film, was used. The program temperature conditions consisted in a temperature program from $40{ }^{\circ} \mathrm{C}$ until $290^{\circ} \mathrm{C}$, with an increment of $4^{\circ} \mathrm{C} / \mathrm{min}$. The injection volume of the sample was $1 \mu \mathrm{L}$ with a split ratio of $100: 1$, using helium as the carrier gas at a flow rate of $0.5 \mathrm{ml}$ per minute. Both injector and detector temperature were maintained at $290^{\circ} \mathrm{C}$. The percentage composition was calculated using peak normalization method assuming equal detector response. The samples were then analyzed by a quadrupole mass spectrometer model HP5972 A with an electron impact ionization at $70 \mathrm{eV}$. The compounds separated were characterized from their mass spectral data using the National Institute of Standards and Technology mass spectrometry library (ADAMS, 2007) and according with their Kovact retention indexes.

\section{House-fly colony}

Specimens were collected on the campus of Fundação Oswaldo Cruz, Rio de Janeiro, and were reared and maintained in the Laboratório de Transmissores de Leishmanioses - Setor de Entomologia Médica e Forense of the same Institution following the methodology used in previous works according to Queiroz \& Milward-de-Azevedo (1991). Flies were kept in cages at room temperature with water and sugar ad libitum. Decaying bovine ground beef was given for the maturation of the ovarioles and to stimulate oviposition. The second generation was reared following the same methodology and newly hatched larvae were used in the experiments.

\section{Bioassay}

Serial dilutions were performed from essential oils of $C$. citratus from Brazil and Cuba dissolved in dimethylsulfoxide (DMSO) (SIGMA - USA) to obtain six different test concentrations: 5\% (25 $\mu \mathrm{L} /$ oil + $475 \mu \mathrm{L} / \mathrm{DMSO}) ; 10 \%(50 \mu \mathrm{L} / \mathrm{oil}+450 \mu \mathrm{L} / \mathrm{DMSO})$; 25\% (125 $\mu \mathrm{L} /$ oil $+375 \mu \mathrm{L} / \mathrm{DMSO}) ; 50 \%$ (250 $\mu \mathrm{L} / \mathrm{oil}+$ $250 \mu \mathrm{L} / \mathrm{DMSO}) ; 75 \%(375 \mu \mathrm{L} / \mathrm{oil}+125 \mu \mathrm{L} / \mathrm{DMSO})$ and $100 \%$ (pure oil). Citral (purchased from Tedia ${ }^{\oplus}$ - Brasil) was prepared by mixing $16.8 \mathrm{mg}$ with $960 \mu \mathrm{L}$ DMSO.

Both essential oils (Brazil's and Cuba's) and citral were applied topically $(1 \mu \mathrm{L} /$ larva $)$ to newly hatched larva bodies of $M$. domestica using micropipettes. In all experimental groups each concentration was performed in quadruplicate using fifty newlyhatched larvae for each replicate. In addition, two control groups were performed (with/without DMSO). After treatment, the newly-hatched larvae were transferred and placed onto recipients with $50 \mathrm{~g}$ of putrefied bovine meat ( $1 \mathrm{~g} / \mathrm{larva}$ ), to guarantee enough food for maximum development. These recipients were placed into larger ones $(500 \mathrm{~mL})$ containing a substrate for pupation and then covered with a nylon cloth held down with rubber bands. Mature larvae (L3), that spontaneously abandoned the diet, were individually weighed in analytical balance and transferred to glass tubes containing vermiculite to one-fourth of their volume and sealed with cotton. The experiments were maintained in acclimatized chambers set at $27 \pm 1^{\circ} \mathrm{C}, 70 \pm 10 \% \mathrm{RH}, 12: 12$ light/ dark cycle. Daily observations were made until the emergence of the adults, with subsequent sex ratio calculation (nFemale/ nFemale+nMale) (RODRIGUES, 2004) and morphologic deformities analysis. Viability and duration of each period (larval, pupal and newly-hatched larvae to adult) were analyzed. Another variable considered was the weight of mature larvae. Results were analyzed by One-way Analysis of Variance (ANOVA) $(P<0,0001)$, and mean values were compared by the Tukey-Kramer test at significance level of 0.05 (ZAR, 1999). Values of $\mathrm{LC}_{50}$ and $\mathrm{LC}_{90}$ were computed with Microsoft Office Excel Program.

\section{Results and Discussion}

\section{Chemical characterization of essential oil}

Compounds identified in C. citratus essential oils from Brazil and Cuba are presented in Table 1. GC/MS analysis allowed the identification of 13 and 12 main chemical components for Brazilian and Cuban oils, respectively. In both of them, the major components were the isomers geranial with 53.2 and $51.14 \%$ and neral with 36.37 and $35.21 \%$ for Brazilian and Cuban samples, respectively. Besides that, other 8 compounds appear in common. The monoterpene myrcene (6.52\%), observed in Cuban sample, was the only differentiating compound that it is present in high relative abundance.

Chemical studies of $C$. citratus in different habitats around the world identified citral as the major volatile constituent (SOLÓRZANO-SANTOS \& MIRANDA-NOVALES, 2012).

Table 1. Chemical composition (\%) of essential oils from fresh leaves of Cymbopogon citratus (DC) Stapf natives from Brazil and Cuba.

\begin{tabular}{|c|c|c|c|c|}
\hline \multirow[t]{2}{*}{ Constituents } & \multicolumn{2}{|c|}{$\begin{array}{l}\text { Percentage } \\
\text { composition }\end{array}$} & \multirow{2}{*}{$\begin{array}{c}\text { Kovat's } \\
\text { R.I. }\end{array}$} & \multirow[t]{2}{*}{ ID } \\
\hline & Brazil & Cuba & & \\
\hline 6-methylhept-5-en-2-one & 0.19 & 0.23 & 936 & MS, RI \\
\hline Camphene & 0.29 & - & 953 & MS, RI \\
\hline Myrcene & - & 6.52 & 988 & MS, RI \\
\hline Limonene & 0.99 & - & 1030 & MS, RI \\
\hline Linalool & 0.42 & 0.69 & 1079 & MS, RI \\
\hline Citronellal & - & 0.16 & 1132 & MS, RI \\
\hline $\mathrm{n}$ - decanal & 0.19 & - & 1214 & MS, RI \\
\hline $\mathrm{Z}$ - citral (Neral) & 36.37 & 35.21 & 1231 & MS, RI \\
\hline Geraniol & 2.66 & 2.23 & 1247 & MS, RI \\
\hline E - citral (geranial) & 53.2 & 51.14 & 1258 & MS, RI \\
\hline 2 - undecanone & 0.22 & 0.35 & 1287 & MS, RI \\
\hline geranyl acetate & 1.5 & 0.20 & 1359 & MS, RI \\
\hline (E) - caryophyllene & 1.03 & - & 1414 & MS, RI \\
\hline 2- tridecanone & - & 0.10 & 1486 & MS, RI \\
\hline$\gamma$-cadinene & 0.27 & 0.27 & 1513 & MS, RI \\
\hline caryophyllene oxide & 0.59 & 0.59 & 1583 & MS, RI \\
\hline Total identified & 97.92 & 97.69 & & \\
\hline
\end{tabular}

ID = Identification methods; MS = comparison of the mass spectrum with those of the computer mass libraries, and Adams (2007); Kovat's RI. = Kovat's Retention Index with those reported in the literature. 
Twelve Brazilian samples submitted to GC/MS indicated the presence of 22 substances, being neral and geranial the major components with variations from 40.7 to $75.4 \%$ (BARBOSA et al., 2006). Pino \& Rosado (2000) identified and quantified neral (38.2\%) and geranial (49.5\%) as the major components of $C$. citratus oil collected in Havana (Cuba) but low amount of myrcene (1.7\%) when compared with our studies. Moreover, compounds such as 6-methyl-5-hepten-2one, linalool and 2-undecanone were found in the essential oils of the lemongrass collected in Brazil and Cuba (COSTA et al. 2005, 2013). Quantity and chemical composition range of essential oil plants of the same species in different regions may be caused by microclimatic factors, phytogeographic, genotype plants and geographical and agronomical conditions, especially soil. Nevertheless, as general rule the major components remain being the same ones, only varying their concentration levels (KUMAR et al., 2011a).

\section{Bioassays}

Post-embryonic development of $M$. dometica appeared to be drastically influenced by treatment with essential oils from Brazil and Cuba, with no difference between them. Larval period at concentrations of 5,10,25 and 100\% showed a delay in development while 50 and $75 \%$ shortened the period duration. For larval, pupal and newly-hatched larvae to adult periods all the concentrations delayed the period time. (Table 2). The insecticidal activity of Mentha piperita Linnaeus and Lavandula angustifolia Mill essential oils were evaluated against house fly and induced a significant prolongation in larval and pupal periods (BOSLY, 2013). In contrast, the duration of the larval, pupal and newly-hatched larvae to adult periods of $M$. domestica with citral treatment were faster in the presence of this substance (3.18; $4.91 ; 7.91$ days respectively), showing a significant difference $(P<0,0001)$ when compared to the control groups (larval period:
5.29 and 6.50 days, pupal period: 5.27 and 5.37days, newlyhatched larvae to adults: 10.54 and 11.85 days, with/without DMSO, respectively) (Table 2). This contradiction turns into a challenge to be clarified.

Biological properties of essential oils can be the result of a synergy of all the major molecules or just the molecules present at higher concentrations. Generally, the main components reflect their biophysical and biological characteristics and the extent of its effects depends on the concentrations when tested alone or included in essential oils (BAKKALI et al., 2008). However, literature suggests that the minor compounds may contribute to an antagonistic effect on the activity of the essential oil (BOTELHO et al., 2007). According to Nascimento et al. (2007) it is also possible that the emulsifying agent affects the activity of metabolites, acting antagonistically or synergistically to active compounds. DMSO has low toxicity and facilitates the penetration of toxic substances to the body, causing serious risks to health. (STURION et al. 1999). According to Brayton (1986) and Richardson (1973), among the properties and physiological/pharmacological effects of DMSO include a rapid and strong penetration of the other substances through biological membranes, it easily penetrates the skin, in five minutes can be detected in the blood and after 20 minutes can be found in all organs of the body. Based on that the choice of DMSO as solvent decreases the chances of the effects observed in post-embryonic development of $M$. domestica are derived from external factors.

The insecticidal activity of $C$. citratus is assigned conventionally to citral, its major component. This isomeric mix has been used as a steaming agent against Culex pipiens quinquefasciatus Say, 1823 (Diptera: Culicidae) (YANG et al., 2005), due to, the antifeeding activity of neral and geranial (LEAL \& UCHIDA, 1998).

Structural characteristics of terpenoids can influence their insecticidal properties (PAVELA, 2008), and based on the degree of saturation and the functional group type can dispose the penetration of the insect cuticle, helping in their degradation (RICE \& COATS, 1994). Although the mechanism of action of

Table 2. Duration (days) of post-embrionic development of Musca domestica (Diptera:Muscidae), treated with different concentrations of essential oil of Cymbopogon citratus from Brazil and Cuba and monoterpene citral, under laboratory conditions.

\begin{tabular}{|c|c|c|c|c|c|c|}
\hline \multirow{4}{*}{ Treatments } & \multicolumn{6}{|c|}{ Duration (days) } \\
\hline & \multicolumn{2}{|c|}{ Larval stage } & \multicolumn{2}{|c|}{ Pupal stage } & \multirow{2}{*}{\multicolumn{2}{|c|}{$\frac{\text { Newly-hatched larvae to adult }}{(\text { Mean } \pm \text { SD })^{*}}$}} \\
\hline & \multicolumn{2}{|c|}{$(\text { Mean } \pm S D)^{*}$} & \multicolumn{2}{|c|}{$(\text { Mean } \pm S D)^{*}$} & & \\
\hline & Brazil & Cuba & Brazil & Cuba & Brazil & Cuba \\
\hline Control & $6.68 \pm 0.47^{a}$ & $6.68 \pm 0.47^{a}$ & $5.23 \pm 0.42^{\mathrm{a}}$ & $5.23 \pm 0.42^{\mathrm{a}}$ & $11.91 \pm 0.29^{\mathrm{a}}$ & $11.91 \pm 0.29^{\mathrm{a}}$ \\
\hline DMSO & $5.31 \pm 0.58^{b}$ & $5.31 \pm 0.58^{\mathrm{b}}$ & $5.31 \pm 0.58^{b}$ & $5.31 \pm 0.58^{\mathrm{b}}$ & $10.63 \pm 1.16^{\mathrm{b}}$ & $10.63 \pm 1.16^{\mathrm{b}}$ \\
\hline $5 \%$ & $7.17 \pm 0.37^{c} \cdot 37.37^{c}$ & $7.14 \pm 0.35^{c}$ & $7.14 \pm 0.34^{\mathrm{b}}$ & $7.12 \pm 0.32^{\mathrm{b}}$ & $14.51 \pm 0.50^{c}$ & $14.42 \pm 0.49^{c}$ \\
\hline $10 \%$ & $7.20 \pm 0.40^{c}$ & $7.15 \pm 0.36^{c}$ & $7.11 \pm 0.31^{\mathrm{b}}$ & $7.10 \pm 0.30^{\mathrm{b}}$ & $14.49 \pm 0.50^{c}$ & $14.39 \pm 0.49^{c}$ \\
\hline $25 \%$ & $7.18 \pm 0.39^{c}$ & $7.17 \pm 0.38^{c}$ & $7.15 \pm 0.36^{\mathrm{b}}$ & $7.13 \pm 0.34^{\mathrm{b}}$ & $14.44 \pm 0.50^{c}$ & $14.43 \pm 0.49^{c}$ \\
\hline $50 \%$ & $5.18 \pm 0.39^{b}$ & $5.19 \pm 0.39^{\mathrm{b}}$ & $7.14 \pm 0.34^{\mathrm{b}}$ & $7.10 \pm 0.31^{\mathrm{b}}$ & $12.55 \pm 0.50^{\mathrm{d}}$ & $12.46 \pm 0.50^{\mathrm{d}}$ \\
\hline $75 \%$ & $5.20 \pm 0.40^{\mathrm{b}}$ & $5.23 \pm 0.42^{\mathrm{b}}$ & $7.17 \pm 0.37^{b}$ & $7.23 \pm 0.42^{\mathrm{b}}$ & $12.56 \pm 0.50^{d}$ & $12.50 \pm 0.50^{\mathrm{d}}$ \\
\hline $100 \%$ & $12.15 \pm 0.36 \mathrm{~d}^{\mathrm{d}}$ & $12.18 \pm 0.39^{d}$ & $7.20 \pm 0.40^{\mathrm{b}}$ & $7.17 \pm 0.38^{\mathrm{b}}$ & $19.52 \pm 0.51^{\mathrm{e}}$ & $19.50 \pm 0.50^{\mathrm{e}}$ \\
\hline Control & \multicolumn{2}{|c|}{$6.50 \pm 0.51^{\mathrm{a}}$} & \multicolumn{2}{|c|}{$5.37 \pm 0.49^{\mathrm{a}}$} & \multicolumn{2}{|c|}{$11.85 \pm 0.36^{\mathrm{a}}$} \\
\hline DMSO & \multicolumn{2}{|c|}{$5.29 \pm 0.47^{b}$} & \multicolumn{2}{|c|}{$5.27 \pm 0.45^{\mathrm{ab}}$} & \multicolumn{2}{|c|}{$10.54 \pm 0.90^{\mathrm{b}}$} \\
\hline Citral & \multicolumn{2}{|c|}{$3.18 \pm 0.40^{c}$} & \multicolumn{2}{|c|}{$4.91 \pm 0.30^{\mathrm{b}}$} & \multicolumn{2}{|c|}{$7.91 \pm 0.30^{c}$} \\
\hline
\end{tabular}

*Values within a column followed by the same letter are not significantly differen at the $5 \%$ level according to Tukey's HSD. Oil test with four replication, N=50 and Citral test with three replication, $\mathrm{N}=10$. DMSO= dimetilsulfoxide. 
essential oils and its constituents is unknown, the appearance of toxic signs is fast (KNAAK \& FIUZA, 2010).

Any of these observations could explain the differences in development time and mortality of $M$. domestica treated with pure citral and citral found in the essential oil diluted in DMSO.

Sex ratio did not differ significantly in any of the treated groups when compared to control groups (Table 3). Larval weight from Brazil and Cuba showed significant difference $(\mathrm{p}<0.0001)$ when compared to control groups.

Lightest larvae (17.53mg oil/Brazil and $17.49 \mathrm{mg}$ oil/Cuba) belong to concentration of $10 \%$ while the heaviest larvae $(27.01 \mathrm{mg}$ oil/Brasil and $26.97 \mathrm{mg}$ oil/Cuba) belong to the concentration of $50 \%$, when compared to control groups with DMSO $(21.59 \mathrm{mg})$ and without DMSO $(21.50 \mathrm{mg})$. Monoterpene citral significantly increased larval weight $(25.65 \mathrm{mg})$ when compared to control groups with DMSO (22.22mg) and without DMSO (21.18mg) (Table 3).
Necrophagous Diptera are more suitable to pupate even when the final weight is below the average estimated for other species (MENDONÇA et al., 2011). According to Lomonaco \& Germanos (2001), the increasing in the development period may be due to delays in obtaining the necessary weight for pupating (ROPER et al., 1996), due to the difficulties in obtaining food. These data are similar to some of the results obtained in this experiment.

Mortality of $M$. domestica in larval, pupal and newlyhatched larvae to adult periods was affected in a dose-dependent manner for both oils. Mortality of newly-hatched larvae showed highly significant values for Brazil and Cuba, respectively: 5\% (62.5 / 61.5); 10\% (62.0 / 63.0); 25\% (64.0/ 65.0); 50\% $(75.0 / 73.0) ; 75 \%(77.5 / 78.0)$ and $100 \%(87.5 / 87.0)$ (Figure 1, 2).

Monoterpene citral presented a slightly higher mortality at all development stages when compared to essential oil of $C$. citratus

Table 3. Larval weight (mg) and sex ratio of Musca domestica (Diptera:Muscidae) treated with essential oil of Cymbopogon citratus from Brazil and Cuba and monoterpene citral, under laboratory conditions.

\begin{tabular}{|c|c|c|c|c|c|c|}
\hline \multirow{3}{*}{ Treatments } & \multicolumn{6}{|c|}{ Weight (mg) } \\
\hline & \multicolumn{2}{|c|}{$(\text { Mean } \pm \text { SD })^{*}$} & \multicolumn{2}{|c|}{ IV } & \multicolumn{2}{|c|}{ Sex ratio } \\
\hline & Brazil & Cuba & Brazil & Cuba & Brazil & Cuba \\
\hline Control & $21.50 \pm 1.76^{\mathrm{a}}$ & $21.50 \pm 1.76^{\mathrm{a}}$ & $19.00-24.40$ & $19.00-24.40$ & 0.50 & 0.50 \\
\hline DMSO & $21.59 \pm 1.39^{\mathrm{a}}$ & $21.59 \pm 1.39^{\mathrm{a}}$ & $15.00-24.20$ & $15.00-24.20$ & 0.51 & 0.51 \\
\hline $5 \%$ & $19.60 \pm 1.41^{\mathrm{b}}$ & $19.50 \pm 1.32^{\mathrm{b}}$ & $17.20-21.50$ & $17.50-21.00$ & 0.50 & 0.50 \\
\hline $10 \%$ & $17.53 \pm 1.23^{c}$ & $17.49 \pm 1.27^{c}$ & $15.80-20.60$ & $15.60-20.60$ & 0.51 & 0.51 \\
\hline $25 \%$ & $20.37 \pm 0.95^{\mathrm{d}}$ & $20.36 \pm 0.93^{d}$ & $19.40-21.80$ & $19.40-21.80$ & 0.51 & 0.49 \\
\hline $50 \%$ & $27.01 \pm 2.18^{\mathrm{e}}$ & $26.97 \pm 2.38^{\mathrm{e}}$ & $21.90-33.00$ & $24.80-33.00$ & 0.54 & 0.53 \\
\hline $75 \%$ & $21.50 \pm 2.65^{f}$ & $21.35 \pm 2.69^{f}$ & $17.40-25.30$ & $17.20-25.20$ & 0.53 & 0.53 \\
\hline $100 \%$ & $22.05 \pm 1.65^{f}$ & $22.39 \pm 2.19^{\mathrm{f}}$ & $19.50-25.60$ & $19.00-25.60$ & 0.53 & 0.52 \\
\hline Control & \multicolumn{2}{|c|}{$21.18 \pm 1.55^{\mathrm{a}}$} & \multicolumn{2}{|c|}{$19.00-24.00$} & \multicolumn{2}{|c|}{0.54} \\
\hline DMSO & \multicolumn{2}{|c|}{$22.22 \pm 1.30^{\mathrm{a}}$} & \multicolumn{2}{|c|}{$20.80 \pm 24.20$} & \multicolumn{2}{|c|}{0.56} \\
\hline Citral & \multicolumn{2}{|c|}{$25.65 \pm 5.42^{\mathrm{b}}$} & \multicolumn{2}{|c|}{$16.50-31.70$} & \multicolumn{2}{|c|}{0.49} \\
\hline
\end{tabular}

*Values within a column followed by the same letter are not significantly differen at the $5 \%$ level according to Tukey's HSD. DMSO= dimetilsulfoxide. Oil test with four replication, $\mathrm{N}=50$ and citral test with three replication, $\mathrm{N}=10$.

Cymbopogon citratus from Brazil

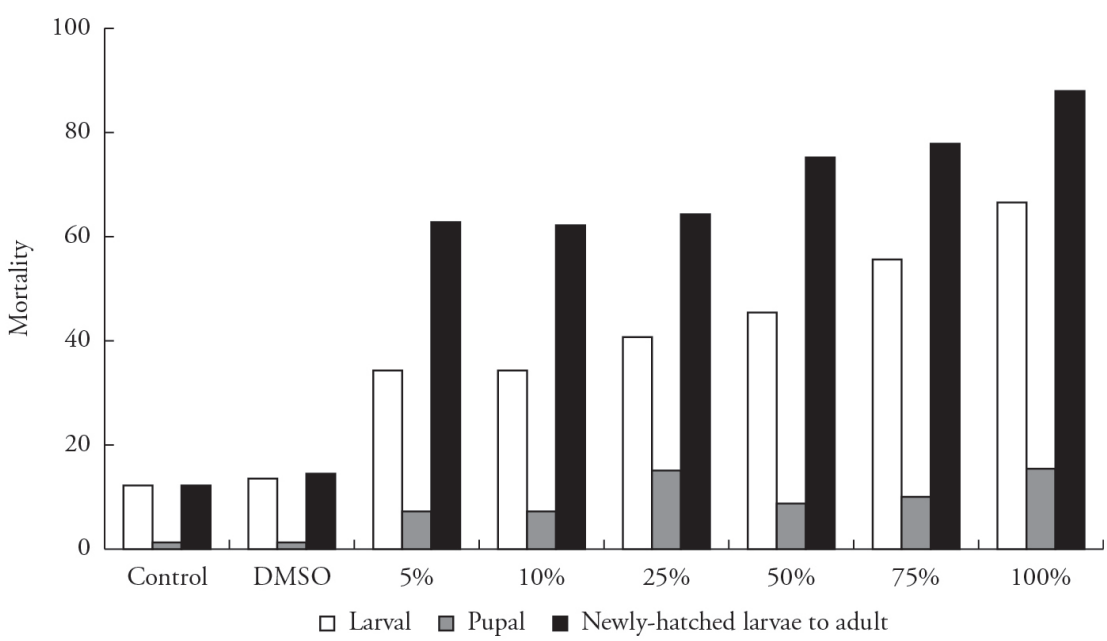

Figure 1. Mortality of larval, pupal and newly-hatched larvae to adult periods of Musca domestica after exposure to different concentrations of Cymbopogon citratus oil from Brazil, under laboratory conditions. 
(Figures 1, 2 and 3). This can be explained by the fact that insecticidal activity of this essential oil has been attributed to its major monoterpene citral (YANG et al., 2005).

Kumar et al. (2011b) testing several essential oils against $M$. domestica, also noted a high rate of mortality after $48 \mathrm{~h}$ exposure. For C. citratus the authors found a mortality rate of $77 \%$. An contact toxicity bioassay of $C$. citratus against $M$. domestica larvae and pupae showed lethal concentration $\left(\mathrm{LC}_{50}\right)$ value of $0.41 \mu \mathrm{l} / \mathrm{cm}^{2}$ and a percentage inhibition rate (PIR) of $7 \%$ and 7.3\%, respectively (KUMAR et al., 2013). Abdel Halim \& Morsy (2006) also observed high mortalities in Muscidae after using essential oils of Cupressus macrocarpa Hartw. (Cupressaceae) and Alpinia officinarum Hance (Zingiberaceae) against Synthesiomyia nudiseta (Wulp, 1883) (Muscidae: Azeliinae).
C. citratus essential oil showed $\mathrm{LC}_{50}$ of 4.25 and $3.24 \%$ and a $\mathrm{LC}_{90}$ of 84.25 and $83.24 \%$ for Brazil and Cuba, respectively. Different concentrations of citral presented a significant larval mortality, with $\mathrm{LC}_{90}$ of 0.19 and $0.09 \mu \mathrm{l} / \mathrm{cm}^{3}$ after 24 and $48 \mathrm{~h}$, respectively, and the other monoterpene 1,8-Cineole $\mathrm{LC}_{90}$ of 0.36 and $0.15 \mu \mathrm{l} / \mathrm{cm}^{3}$ for the same interval time (KUMAR et al., 2013). Khater et al. (2011) working with Egiptian essential oils showed a high effectiveness against Lucilia sericata (Meigen, 1826) (Diptera: Calliphoridae) with $\mathrm{LC}_{50}$ values of $0.57,0.85,2.74$ and $6.77 \%$ for lettuce, chamomile, anise and rosemary, respectively, slowing larval growth at sublethal concentrations. Dipping assay using lemongrass demonstrated $\mathrm{LC}_{50}$ of 69ppm against Aedes aegypti (Linneaus, 1972) (Diptera:Culicidae) and C. quinquefasciatus larvae a $\mathrm{LC}_{50}$ of $144 \mathrm{ppm}$. The essential oil of $C$. citratus showed to have a great larvicidal activity against $A$. aegypti and caused $100 \%$

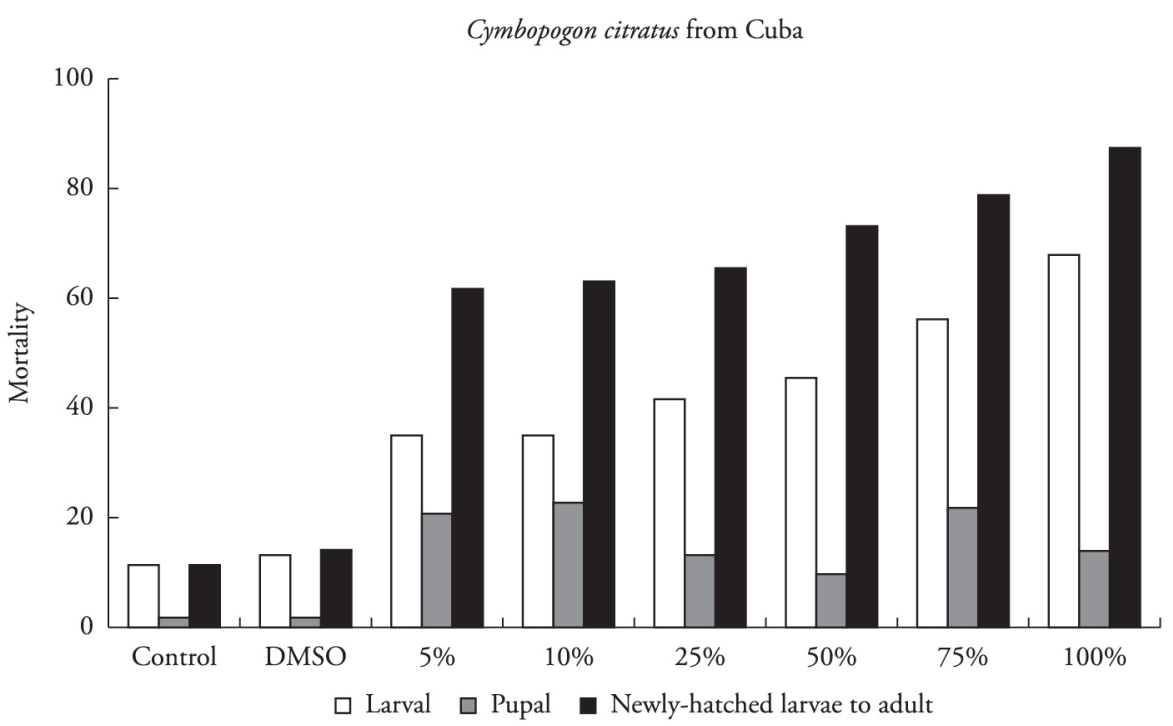

Figure 2. Mortality of larval, pupal and newly-hatched larvae to adult periods of Musca domestica after exposure to different concentrations of Cymbopogon citratus oil from Cuba, under laboratory conditions.

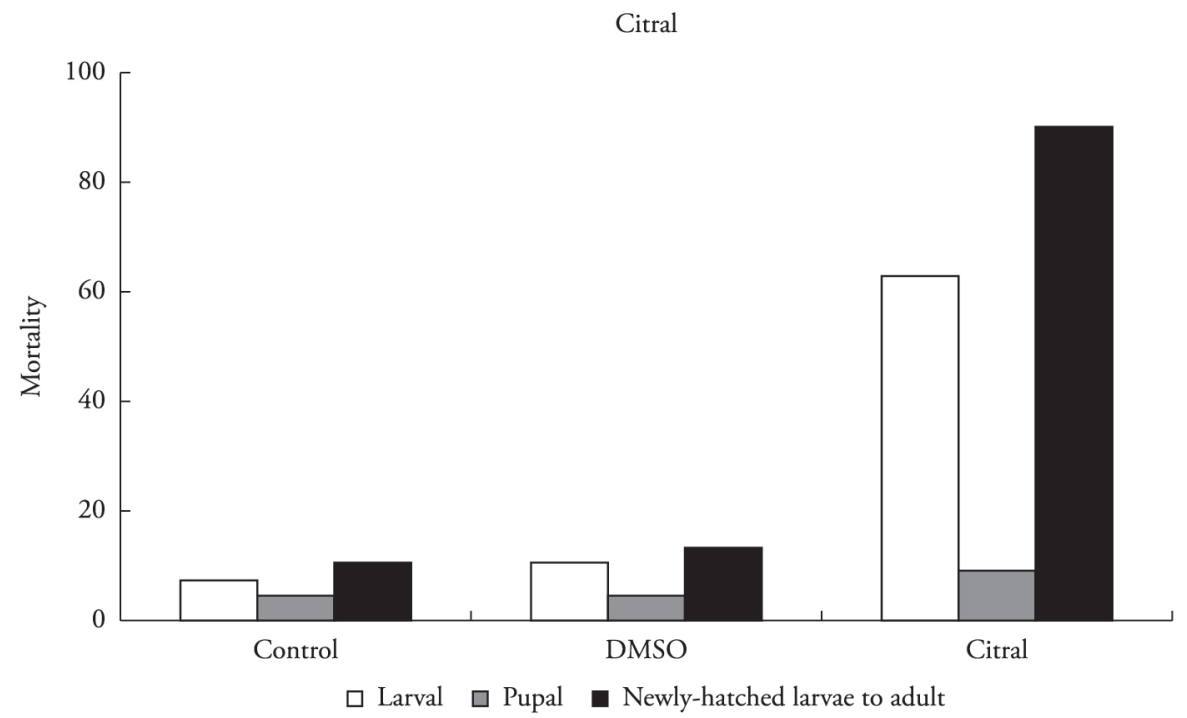

Figure 3. Mortality of larval, pupal and newly-hatched larvae to adult periods of Musca domestica after exposure to Citral, under laboratory conditions. 
Table 4. Percentage (\%) of morphological deformities from adults of Musca domestica treated with essential oil of Cymbopogon citratus from Brazil and Cuba and monoterpene citral, under laboratory conditions.

\begin{tabular}{|c|c|c|}
\hline & Morpho & ities (\%) \\
\hline Treatments & Brazil & Cuba \\
\hline Control & 0.00 & 0.00 \\
\hline DMSO & 0.00 & 0.00 \\
\hline $5 \%$ & 38.67 & 37.66 \\
\hline $10 \%$ & 55.26 & 56.76 \\
\hline $25 \%$ & 76.39 & 78.57 \\
\hline $50 \%$ & 81.13 & 80.65 \\
\hline $75 \%$ & 86.67 & 88.64 \\
\hline $100 \%$ & 100.00 & 100.00 \\
\hline Control & \multicolumn{2}{|c|}{0.00} \\
\hline DMSO & \multicolumn{2}{|c|}{0.00} \\
\hline Citral & \multicolumn{2}{|c|}{100.00} \\
\hline
\end{tabular}

$\mathrm{DMSO}=$ dimetilsulfoxide. Oil test with four replication, $\mathrm{N}=50$ and citral test with three replication, $\mathrm{N}=10$.

mortality at a concentration of 100 ppm (CAVALCANTI et al., 2004).

The abnormality rate in adults from $M$. domestica showed a dose-dependency, with $100 \%$ of deformity at concentrations of $100 \%$, both for Brazil and Cuba's essential oils and for the citral (Table 4). Elkattan et al. (2011), using different substances observed a reduction in adult emergence rate, favoring the development of male. Longevity of both sexes was affected when compared to the control. All lethal doses of Pelargonium zonale (Linnaeus) L'Her (Geraniaceae), Cyperus rotundus Linnaeus (Cyperaceae), Acacia nilotica Linnaeus (Fabacea), Cupressus macrocarpa Hartw. (Cupressaceae) and lethal doses $\mathrm{LC}_{50}$ and $\mathrm{LC}_{75}$ of Lantana camara Linnaeus (Verbenaceae) caused a significant reduction in the fecundity of adult females, in addition to morphological changes at all development stages. Pure extract of Francoeuria crispa (Forssk., Cas.) (Asteraceae) extracted with hexane, ethyl ether and ethyl acetate caused deformities in adults of Chrysomyia albiceps (Wiedemann, 1819) (Diptera: Calliphoridae) Abdel-Shafy et al. (2009). Khater et al. (2011) also noted that essencial oil of Lactuca sativa Linnaeus (Asteraceae) led to a higher percentage of deformities in L. sericata at all development stages. These deformations are due to the fact that some substances extracted from plants can cause changes in the endocrine system by directly attacking the hormones production (CABRAL et al., 1999).

In conclusion, results from Brazilian and Cuban essential oils and its monoterpenoid citral showed significant alterations on post-embryonic development of $M$. domestica, demonstrating its potential insecticidal activity. The oils and citral can be used in further formulations for breeding control and to avoid reinfestations.

\section{Acknowledgments}

This work was supported by grants from Coordenação de Aperfeiçoamento de Pessoal de Nível Superior (CAPES), Instituto Oswaldo Cruz (IOC/FIOCRUZ).

\section{References}

Abdel Halim AS, Morsy TA. Efficacy of Trigonella foenum-graecum (fenugreek) on third stage larvae and adult fecundity of Musca domestica. J Egypt Soc Parasitol 2006; 36(1): 329-334. PMid:16605122.

Abdel-Shafy S, El-Khateeb RM, Soliman MMM, Abdel-Aziz MM. The efficacy of some wild medicinal plant extracts on the survival and development of third instar larvae of Chrysomyia albiceps (Wied) (Diptera: Calliphoridae). Trop Anim Health Prod 2009; 41(8): 1741-1753. http:// dx.doi.org/10.1007/s11250-009-9373-0. PMid:19455398

Adams RP. Identification of essential oil components by Gas Chromatography/ Mass Spectrometry. 4th ed. Illinois: Allured Publishing Corporation; 2007.

Agência Nacional de Vigilância Sanitária - Anvisa. Farmacopeia Brasileira. 5a ed. Brasília; 2010. p. 189-204.

Anderson DL, Trueman JWH. Varroa jacobsoni (Acari: Varroidae) is more than one species. Exp Appl Acarol 2000; 24(3): 165-189. http://dx.doi. org/10.1023/A:1006456720416. PMid:11108385

Bakkali F, Averbeck S, Averbeck D, Idaomar M. Biological effects of essential oils_a review. Food Chem Toxicol 2008; 46(2): 446-475. http:// dx.doi.org/10.1016/j.fct.2007.09.106. PMid:17996351

Barbosa FF, Barbosa LCA, Melo EC, Botelho FM, Santos RHS Influência da temperatura do ar de secagem sobre o teor e a composição química do óleo essencial de Lippia alba (Mill) N. E. Brown. Quim Nova 2006; 29(6): 1221-1225. http://dx.doi.org/10.1590/S010040422006000600014.

Barin A, Arabkhazaeli F, Rahbari S, Madani SA. The housefly, Musca domestica, as a possible mechanical vector of Newcastle disease virus in the laboratory and field. Med Vet Entomol 2010; 24(1): 88-90. http:// dx.doi.org/10.1111/j.1365-2915.2009.00859.x. PMid:20377736

Bosly AH. Evaluation of insecticidal activities of Mentha piperita and Lavandula angustifolia essential oils against house fly, Musca domestica L. (Diptera: Muscidae). J Entomol Nematol 2013; 5(4): 50-54. http:// dx.doi.org/10.5897/JEN2013.0073.

Botelho MA, Nogueira NAP, Bastos GM, Fonseca SGC, Lemos TL, Matos FJA, et al. Antimicrobial activity of the essential oil from Lippia sidoides, carvacrol and thymol against oral pathogens. Braz J Med Biol Res 2007; 40(3): 349-356. http://dx.doi.org/10.1590/S0100879X2007000300010. PMid:17334532

Brayton CF. Dimethyl sulfoxide (DMSO): a review. Cornell Vet 1986; 76(1): 61-90. PMid:3510103.

Cabral MMO, Kelecom A, Garcia ES. Effects of the lignan, pinoresinol on the moulting cycle of the bloodsucking bug Rhodnius prolixus, and of the milkweed bug Oncopeltus fasciatus. Fitoterapia 1999; 70(6): 561-567. http://dx.doi.org/10.1016/S0367-326X(99)00089-1.

Cavalcanti ESB, Morais SM, Lima MAA, Santana EWP. Larvicidal activity of essential oils from Brazilian plants against Aedes aegypti L. Mem Inst Oswaldo Cruz 2004; 99(5): 541-544. http://dx.doi.org/10.1590/ S0074-02762004000500015. PMid:15543421

Costa LCB, Corrêa RM, Cardoso JCW, Pinto JEBP, Bertolucci SKV, Ferri PH. Secagem e fragmentação da matéria seca no rendimento e composição do óleo essencial de capim - limão. Hortic Bras 2005; 23(4): 956-959. http://dx.doi.org/10.1590/S0102-05362005000400019.

Costa AV, Pinheiro PF, Rondelli VM, Queiroz VT, Tuler AC, Brito $\mathrm{KB}$, et al. Cymbopogon citratus (Poaceae) essential oil on Frankliniella 
schultzei (Thysanoptera: Thripidae) and Myzus persicae (Hemiptera: Aphididae). Biosci J 2013; 29(6): 1840-1847.

Duarte MR, Zaneti CC. Estudo farmacobotânico de folhas do capimlimão: Cymbopogon citratus (DC.) Stapf, Poaceae. Visão Acadêmica 2004; 5(2): 117-124.

Elkattan NAI, Ahmed KS, Elbermawy SM, Abdel-Gawad RM. Effect of some botanical materials on certain biological aspects of the house fly, Musca domestica L. Egypt J Hosp Med 2011; 42: 33-48.

Fazolin M, Estrela JLV, Catani V, Alécio MR, Lima SL. Atividade inseticida do óleo essencial de Tanaecium nocturnum (Barb. Rodr.) Bur. $\&$ K. Shum (Bignoneaceae) sobre Sitophilus zeamais Motsch. (Coleoptera: Curculionidae). Acta Amazon 2007; 37(4): 599-603. http://dx.doi. org/10.1590/S0044-59672007000400015.

Garcia ES, Azambuja P. Lignoids in insects: chemical probes for the study of ecdysis, excretion and Trypanosoma cruzi - triatomine interactions. Toxicon 2004; 44(4): 431-440. http://dx.doi.org/10.1016/j. toxicon.2004.05.007. PMid:15302525

Ghasemi V, Moharramipour S, Tahmasbi G. Biological activity of some plant essential oils against Varroa destructor (Acari: Varroidae), an ectoparasitic mite of Apis mellifera (Hymenoptera: Apidae). Exp Appl Acarol 2011; 55(2): 147-154. http://dx.doi.org/10.1007/s10493-0119457-1. PMid:21484423

Grabovac S, Petrić D. The fly fauna (Diptera: Cyclorrapha) on animal farms. Acta Entomol Serbica 2003; 8(1-2): 63-72.

Isman MB. Botanical insecticides, deterrents, and repellents in modern agriculture and an increasingly regulated world. Annu Rev Entomol 2006; 51(1): 45-66. http://dx.doi.org/10.1146/annurev. ento.51.110104.151146. PMid:16332203

Khater HF, Hanafy A, Abdel-Mageed AD, Ramadan MY, El-Madawy RS. Control of the myiasis-producing fly, Lucilia sericata, with Egyptian essential oils. Int J Dermatol 2011; 50(2): 187-194. http://dx.doi. org/10.1111/j.1365-4632.2010.04656.x. PMid:21244384

Knaak N, Fiuza LM. Potencial dos óleos essenciais de plantas no controle de insetos e microrganismos. Neotrop Biol Conserv 2010; 5(2): 120-132. http://dx.doi.org/10.4013/nbc.2010.52.08.

Koul O, Walia S, Dhaliwal GS. Essential oils as green pesticides: potential and constraints. Biopestic Int 2008; 4(1): 63-84.

Kumar P, Mishra S, Malik A, Satya S. Insecticidal properties of Mentha species: a review. Ind Crops Prod 2011a; 34(1): 802-817. http://dx.doi. org/10.1016/j.indcrop.2011.02.019.

Kumar P, Mishra S, Malik A, Satya S. Repellent, larvicidal and pupicidal properties of essential oils and their formulations against the housefly, Musca domestica. Med Vet Entomol 2011b; 25(3): 302-310. http://dx.doi. org/10.1111/j.1365-2915.2011.00945.x. PMid:21338379

Kumar P, Mishra S, Malik A, Satya S. Insecticidal evaluation of essential oils of Citrus sinensis L. (Myrtales: Myrtaceae) against housefly, Musca domestica L. (Diptera: Muscidae). Parasitol Res 2012; 110(5): 1929-1936. http://dx.doi.org/10.1007/s00436-011-2719-3. PMid:22127387

Kumar P, Mishra S, Malik A, Satya S. Housefly (Musca domestica L.) control potential of Cymbopogon citratus Stapf. (Poales: Poaceae) essential oil and monoterpenes (citral and 1,8-cineole). Parasitol Res 2013; 112(1): 69-76. http://dx.doi.org/10.1007/s00436-012-3105-5. PMid:22955501

Leal WS, Uchida K. Application of GC-EAD to the determination of mosquito repellents derived from a plant, Cymbopogon citratus. J Asia
Pac Entomol 1998; 1(2): 217-221. http://dx.doi.org/10.1016/S12268615(08)60022-9.

Liu SQ, Shi JJ, Cao H, Jia FB, Liu XQ, Shi GL. Survey of pesticidal componentes in plant. In: Benjing L. Entomology in China in 21 st Century. China: Science \& Technique Press; 2000. p. 1098-1104.

Lomônaco C, Germanos E. Variaçôes fenotípicas em Musca domestica L. (Diptera: Muscidae) em resposta à competição larval por alimento. Neotrop Entomol 2001; 30(2): 223-231. http://dx.doi.org/10.1590/ S1519-566X2001000200004.

McAllister JC, Adams MF. Mode of action for natural products isolated from essential oils of two trees is different from available mosquito adulticides. J Med Entomol 2010; 47(6): 1123-1126. http://dx.doi. org/10.1603/ME10098. PMid:21175062

Mendonça PM, Lima MG, Albuquerque LRM, Carvalho MG, Queiroz MMC. Effects of latex from "Amapazeiro" Parahancornia amapa (Apocynaceae) on blowfly Chrysomya megacephala (Diptera: Calliphoridae) post-embryonic development. Vet Parasitol 2011; 178(3-4): 379-382. http://dx.doi.org/10.1016/j.vetpar.2011.01.002. PMid:21292402

Nascimento PFC, Nascimento AC, Rodrigues CS, Antoniolli AR, Santos PO, Barbosa Junior AM, et al. Antimicrobial activity of the essentials oils: a multifactor approach of the methods. Rev Bras Farmacogn 2007; 17(1): 108-113.

Pavela R. Insecticidal properties of several essential oils on the house fly (Musca domestica L.). Phytother Res 2008; 22(2): 274-278. http://dx.doi. org/10.1002/ptr.2300. PMid:17886229

Pino JA, Rosado A. Chemical composition of the essential oil of Cymbopogon citratus (DC.) Stapf. From Cuba. J Essent Oil Res 2000; 12(3): 301-302. http://dx.doi.org/10.1080/10412905.2000.9699521.

Prado AP. Controle das principais espécies de moscas em áreas urbanas. Biológico 2003; 65(1-2): 95-97.

Prates HT, Santos JP. Óleos essenciais no controle de pragas de grãos armazenados. In: Lorini I, Miike LH, Scussel VM, editores. Armazenagem de grãos. Campinas: Instituto Bio Geneziz; 2002. p. 443-461.

Queiroz MMC, Milward-de-Azevedo EMV. Técnicas de criação e alguns aspectos da biologia de Chrysomya albiceps (Wiedemann) (Diptera, Calliphoridae), em condiçóes de laboratório. Rev Bras Zool 1991; 8(1-4): 75-84. http://dx.doi.org/10.1590/S0101-81751991000100006.

Rice PJ, Coats JR. Structural requirements for monoterpenoid activity against insects. In: Hedin PA. Bioregulators for crop protection and pest control. Washington: American Chemical Society; 1994. p. 92-108.

Richardson J. Topical use of dimethyl sulfoxide (DMSO). Spring; 1973; p. 223-225

Rodrigues WC. Utilização da informática na entomologia. Info Insetos 2004; 1(2): 1-10.

Roper C, Pignatelli P, Partridge L. Evolutionary responses of Drosophila melanogaster life history to differences in larval density. J Evol Biol 1996; 9(5): 609-622. http://dx.doi.org/10.1046/j.1420-9101.1996.9050609.x.

Shah G, Shri R, Panchal V, Sharma N, Singh B, Mann AS. Scientific basis for the therapeutic use of Cymbopogon citratus, stapf (Lemon grass).J Adv Pharm Technol Res 2011; 2(1):3-8. http://dx.doi.org/10.4103/22314040.79796. PMid:22171285 
Sinthusiri J, Soonwera M. Efficacy of herbal essential oils as insecticides against the housefly, Musca domestica L. Southeast Asian J Trop Med Public Health 2013; 44(2): 188-196.

Solórzano-Santos F, Miranda-Novales MG. Essential oils from aromatic herbs as antimicrobial agents. Curr Opin Biotechnol 2012; 23(2): 136141. http://dx.doi.org/10.1016/j.copbio.2011.08.005. PMid:21903378

Sousa SM, Silva PS, Viccini LF. Cytogenotoxicity of Cymbopogon citratus (DC) Stapf (lemon grass) aqueous extracts in vegetal test systems. An Acad Bras Cienc 2010; 82(2): 305-311. http://dx.doi.org/10.1590/ S0001-37652010000200006. PMid:20563411

Sturion DJ, Pinheiro ER, Pardo PE, Tanaka NM. Efeitos hepatotóxicos e nefrotóxicos do dimetil sulfóxido em aplicaçôes tópicas em cães. UNOPAR Cient Ciênc Biol Saúde 1999; 1(1): 41-47.
Tangpu V, Yadav AK. Antidiarrhoead activity of Cymbopogon citratus and its main constituent, citral. Pharmacologyonline 2006; 48: 290-298.

Vazirianzadeh B, Solary SS, Rahdar M, Hajhossien R, Mehdinejad M. Identification of bacteria which possible transmitted by Musca domestica (Diptera: Muscidae) in the region of Ahvaz, SW Iran. Jundishapur J Microbiol 2008; 1(1): 28-31.

Zar JH. Biostatistical analysis. 4th ed. New Jersey: Prentice-Hall; 1999. $663 \mathrm{p}$.

Zumpt F. Myiasis in man and animals in the old world. A textbook for phydicians, veterinarians and zoologists. London: Butterworths; 1985. $267 \mathrm{p}$.

Yang P, Ma Y, Zheng S. Adulticidal activity of five essential oils against Culex pipiens quinquefasciatus. J Pest Sci 2005; 30(2): 84-89. 